\title{
Mixed Dementia: Tinjauan Diagnosis dan Tatalaksana
}

\author{
Wiwit Ida Chahyani ${ }^{1}$, Murni Sri Hastuti ${ }^{*}$ \\ 1) Departemen Neurologi, Fakultas Kedokteran dan Kesehatan, Universitas Muhammadiyah Jakarta \\ *Corresponding author: m.srihastuti@umj.ac.id
}

\begin{abstract}
Background: The prevalence of dementia is currently increasing, regarding the age above 65 years and the risk increases 2 times every 5 years of addition. One type of dementias is mixed dementia. The diagnosis of mixed dementia is very difficult and presents the challenges for clinicians. Therefore, in this article, the author wants to discuss a review of the diagnosis and management of mixed dementia. Results: The diagnosis of mixed dementia uses several criterias such as the International Classification of Diseases and Health Related Problems 10th Revision (ICD-10), the Alzheimer's Disease Diagnostic and Treatment Centers (ADDTC), and the National Institute of Neurological Disorders and Stroke and Association Internationale pour la Recherche et l'Enseignement en Neurosciences (NINDS-AIREN). Management of mixed dementia consists of pharmacological therapy for symptoms of cognitive disorders by administering the cholinesterase inhibitor and NMDA antagonist. Pharmacological therapy for psychological and behavioral disorders with antipsychotics or antidepressants. Management of risk factors for hypertension, consumption of healthy nutrition, and regular exercise can be a preventive measure and prevent the progression of mixed dementia. Conclussion: The Diagnosis of mixed dementia includes the clinical symptoms of Alzheimer's dementia and dementia in cerebrovascular diseases. Management of mixed dementia are therapy for cognitive, psychological, behavioral disorders, and risk factors for cerebrovascular disease. Further research is needed, as well as national and international consensus on the diagnosis and management of mixed dementia in order to achieve a comprehensive management.
\end{abstract}

Keywords: Mixed Dementia, Alzheimer's Disease, Cerebrovascular Disease.

\begin{abstract}
ABSTRAK
Latar Belakang: Prevalensi demensia saat ini semakin meningkat, mengenai usia diatas 65 tahun dan risikonya meningkat 2 kali setiap penambahan usia 5 tahun. Salah satu bentuk demensia adalah mixed dementia. Diagnosis mixed dementia sangat sulit dan memberikan tantangan tersendiri bagi para klinisi. Pada artikel ini, penulis ingin membahas mengenai tinjauan diagnosis dan tatalaksana mixed dementia. Hasil: Diagnosis mixed dementia dapat menggunakan beberapa kriteria yaitu International Classification of Diseases and Health Related Problems 10th Revision (ICD-10), the Alzheimer's Disease Diagnostic and Treatment Centers (ADDTC), dan the National Institute of Neurological Disorders and Stroke and Association Internationale pour la Recherche et l'Enseignement en Neurosciences (NINDSAIREN). Tatalaksana mixed dementia berupa terapi farmakologi untuk gejala gangguan kognitif dengan pemberian golongan inhibitor kolinesterase dan antagonis NMDA. Terapi farmakologi untuk gangguan psikis dan perilaku dengan antipsikotik atau antidepresan. Managemen faktor risiko hipertensi, konsumsi nutrisi yang sehat, dan olah raga teratur sebagai
\end{abstract}


upaya preventif dan mencegah progresivitas mixed dementia. Kesimpulan: Diagnosis mixed dementia meliputi gejala demensia Alzheimer dan demensia pada penyakit serebrovaskuler. Tatalaksana mixed dementia meliputi terapi gangguan kognitif, psikis, dan perilaku, serta tatalaksana faktor risiko penyakit serebrovaskuler. Dibutuhkan penelitian lebih lanjut serta adanya konsensus diagnosis dan tatalaksana mixed dementia baik nasional maupun internasional agar tercapai tatalaksana secara komprehensif.

Kata kunci: Mixed dementia, Penyakit Alzheimer, Penyakit Serebrovaskuler.

\section{PENDAHULUAN}

Di seluruh dunia terdapat 47 juta orang hidup dengan demensia dan pada tahun 2050 jumlahnya diperkirakan akan meningkat menjadi 131 juta (1). Demensia merupakan bagian dari masalah geriatri yang umum ditemukan, mengenai usia diatas 65 tahun. Kejadian demensia meningkat dua kali lipat setiap pernambahan usia 5 tahun. Demensia merupakan salah satu penyebab utama disabilitas pada usia lanjut. Orang dengan demensia memiliki kesulitan untuk hidup mandiri, kesulitan dalam fungsi sosial, dan pekerjaan. Ketidakmampuan ini akan bertambah seiring dengan beratnya demensia (2).

Salah satu bentuk demensia yang paling umum adalah mixed dementia, biasanya merupakan kombinasi dari penyakit neurodegeneratif yang umum terjadi saat penuaan. Kasus yang paling sering adalah penyakit Alzheimer dan adanya kontribusi vaskuler. Penyakit neurodegeneratif umum lainnya yang menyebabkan demensia adalah penyakit Lewy body dan demensia frontotemporal (1). Pada studi patologi, mixed dementia ditemukan pada $46 \%$ orang yang didiagnosis secara klinis sebagai penyakit Alzheimer (3). Studi neuropatologi lainnya menyebutkan prevalensi mixed dementia mencapai $22 \%(4,5)$.

Diagnosis mixed dementia sangat sulit dan memberikan tantangan tersendiri bagi para klinisi. Oleh karena itu pada artikel ini, penulis ingin membahas mengenai tinjauan diagnosis dan tatalaksana mixed dementia.

\section{TINJAUAN LITERATUR \\ Definisi}

Secara definisi demensia membutuhkan penurunan lebih dari satu domain kognitif (memori, praksis, gnosis, bahasa, keterampilan visuospasial, fungsi eksekutif), dan mungkin disertai dengan satu atau lebih gangguan perilaku (depresi, kecemasan, perubahan kepribadian, halusinasi, dan delusi) (6). Mixed dementia adalah koeksistensi penyakit Alzheimer dan penyakit serebrovaskuler pada seorang pasien demensia (4).

\section{Patogenesis}

Seperti pada demensia lainnya, patogenesis mixed dementia dapat mulai pada beberapa tahun sebelum gejala klinis muncul. Sudah disampaikan sebelumnya bahwa mixed dementia adalah koeksistensi penyakit Alzheimer dan penyakit serebrovaskuler. Perubahan mikrovaskuler yang terjadi pada otak orang tua dan penyakit Alzheimer dapat berupa menurunnya perfusi pembuluh darah otak, transport, dan penggunaan glukosa, hilangnya inervasi vaskuler yang berpengaruh pada defisit kolinergik dan neurotransmiter lainnya, gangguan pada regulasi serebrovaskuler neurogenik, perubahan ultrastruktural pada 


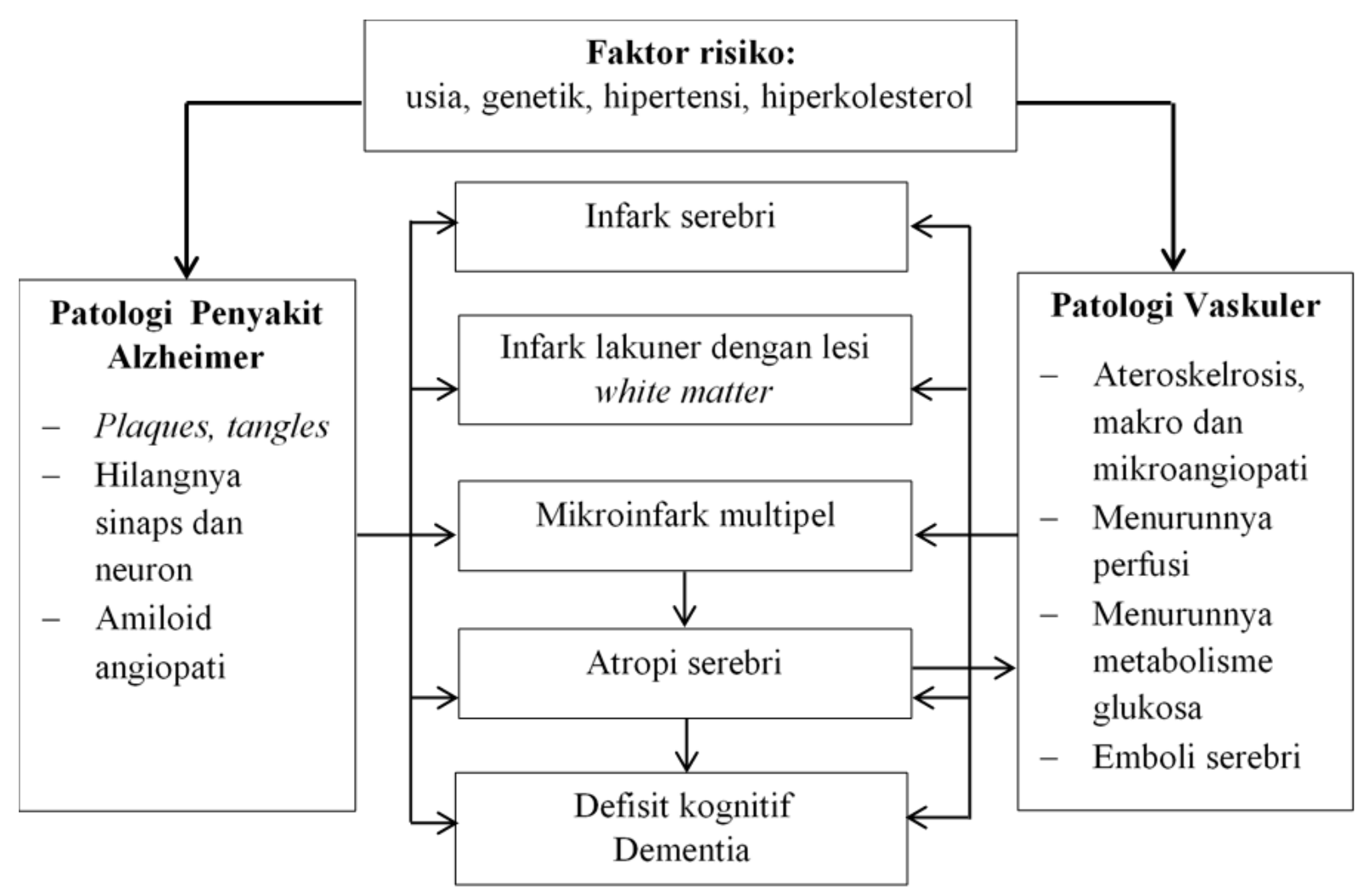

Gambar 1. Patofisiologi Mixed Dementia (Sumber: Jellinger KA, et al., 2007)

kapiler dan membran basal, deposit dari beta amiloid $(\mathrm{A} ß)$ dengan kerusakan pada sawar darah otak dan gangguan clearance amyloid. Berbagai perubahan patogenik ini pada akhirnya akan menghasilkan disintegrasi struktur serebral (lesi lakuner, infark, lesi white matter) yang mengganggu metabolisme neuronal, defisiensi mitokondria, stres oksidatif, dan degradasi protein menyebabkan lesi sitoskeletal dan deposisi dari $\mathrm{A} ß$ dan pembentukan neuritic lesions (fibrillary tangles). Kedua faktor ini pada akhirnya akan menyebabkan atropi otak dengan gangguan memori dan kognitif (Gambar 1) (7).

Baik hipertensi dan amiloid angiopati serebri berhubungan dengan peningkatan prevalensi infark serebri. Faktor serebrovaskuler terhadap peptida $A B$ menyebabkan otak pada usia tua mudah untuk mengalami iskemik. Baik aterosklerosis dan amiloid angiopati serebri menyebabkan perubahan autoregulasi pada mikrovaskuler menyebabkan hilangnya mielin (sering ditemui pada usia tua dan penyakit serebrovaskuler). Faktor risiko yang saling berbagi ini ada pada penyakit Alzheimer, demensia vaskuler, dan mixed dementia. Lesi white matter pada penyakit Alzheimer berhubungan dengan atropi korteks dan lobus temporal medial dan berhubungan dengan penurunan kognitif. Kombinasi penyakit Alzheimer dan vaskuler seperti pada mixed dementia dapat bersamaan pada stadium awal penyakit dari penurunan kognitif dan mempengaruhi keparahan penyakit (Gambar 1) (7).

\section{Diagnosis Klinis}

Diagnosis klinis yang adekuat untuk masing-masing tipe demensia sangat penting untuk mendapatkan hasil terapi yang optimal, namun untuk menentukan perbedaan diantaranya merupakan hal yang sangat sulit (4). Terdapat beberapa pedoman untuk diagnosis mixed dementia, 
seperti International Classification of Diseases and Health Related Problems 10th Revision (ICD-10), the Alzheimer's Disease Diagnostic and Treatment Centers (ADDTC), dan the National Institute of Neurological Disorders and Stroke and Association Internationale pour la Recherche et l'Enseignement en Neurosciences (NINDS-AIREN) (4).

Berdasarkan ICD-10, diagnosis mixed dementia, ditegakkan pada pasien yang memenuhi kriteria demensia vaskuler dan penyakit Alzheimer. Berdasarkan kriteria ADDTC, diagnosis mixed dementia, ditegakkan jika terdapat adanya gejala tipikal penyakit Alzheimer dan demensia yang berhubungan erat dengan penyakit serebrovaskuler. Berdasarkan kriteria NINDS-AIREN diagnosis mixed dementia ditegakkan jika ada bukti sebagai berikut: gangguan memori dan $\geq 2$ domain area kognitif lainnya, terdapatnya injuri vaskuler serebri berupa tanda defisit neurologis fokal dan deteksi adanya lesi white matter dari pencitraan otak, serta onset demensia terjadi dalam 3 bulan pertama setelah stroke (4).

Karena kurangnya konsensus tentang kriteria diagnostik mixed dementia dan gambaran karakteristik neuropatologi yang heterogen, maka mixed dementia belum banyak dipelajari. Namun, menentukan profil kognitif dalam kaitannya dengan penyakit Alzheimer, dapat berguna untuk mengukur kontribusi penyakit serebrovaskuler terhadap gangguan kognitif dan hal ini dapat membantu manajemen klinis dan strategi terapeutik pada pasien dengan mixed dementia (4).

$$
\text { Terdapat penelitian yang }
$$

menunjukkan bahwa tampilan kognitif pada pasien mixed dementia lebih rendah daripada yang diamati pada pasien dengan demensia Alzheimer, terutama pada ranah atensi, memori, denominasi, visuokonstruksi, dan fungsi eksekutif. Demikian pula, pada pasien dengan demensia Alzheimer, subkelompok yang mengalami infark serebri menunjukkan keterlibatan yang lebih besar pada memori, bahasa, denominasi, verbal fluensi, dan praksis konstruktif (4). Selain gangguan kognitif, pada mixed dementia dapat muncul gangguan psikologi dan perilaku berupa apatis, depresi, agitasi, agresi, wandering, gangguan tidur, dan gejala psikotik (delusi dengan/ tanpa halusinasi) (2).

Pemeriksaan pencitraan otak sangat berguna untuk meningkatkan diagnosis secara pasti terutama pada silent lesions seperti infark lakuner dan lesi white matter. Bagaimanpun tidak ada gambaran pencitraan otak yang patognomik dari mixed dementia. Hasil temuan klinis harus diinterpretasikan secara klinis pada masingmasing individu. Menurut VASCOG hubungan yang dekat antara kejadian vaskuler dan tanda/ gejala kognitif harus ada dalam waktu 3 bulan kejadian vaskuler (4).

\section{Tatalaksana}

Tatalaksana mixed dementia bersifat simptomatik dan preventif. Terapi farmakologi dibagi menjadi dua yaitu terapi untuk gejala kognitif dan terapi untuk gejala psikologi serta gangguan perilaku (2). Penggunaan inhibitor asetilkolinesterase (donepezil, galantamin, rivastigmin) dan antagonis $N$-methyl-Daspartatel NMDA (memantin) dapat digunakan pada pasien penyakit Alzheimer dan demensia vaskuler. Pada suatu studi penggunaan obat tersebut pada mixed dementia menunjukkan perbaikan yang minimal pada fungsi kognitif dan tidak ada keunggulan obat secara statistik mengenai 
efektivitas setiap obat terhadap aktivitas sehari-hari dan status global. Pada kasus demensia dengan gangguan psikologi dan perilaku dapat diberikan antipsikotik seperti risperidon atau antidepresan golongan selective serotonin reuptake inhibitors (SSRI) seperti citalopram (2).

Tatalaksana non farmakologi dapat berupa pola makan yang sehat mencakup lebih banyak sayuran, buah-buahan, kacang-kacangan, protein kedelai, bijibijian, dan ikan, serta kurangi konsumsi daging merah. Penelitian longitudinal telah menunjukkan bahwa regimen diet ini dapat menurunkan laju progresivitas gangguan kognitif dan risiko berkembangnya demensia Alzheimer (8). Begitu juga dengan olahraga teratur $(\geq 30$ menit selama $\geq 3$ kali per minggu) menunjukkan penurunan perkembangan gejala kognitif yang terkait dengan demensia Alzheimer dan demensia vaskuler, meningkatkan kemandirian, dan menjaga aktivitas kehidupan sehari-hari (9). Terakhir, dukungan psikologis dan sosial sangat penting, terutama saat pasien sedang bekerja. Dukungan ini juga harus mencakup keluarga, yang harus memahami hilangnya kemandirian pasien secara progresif (4).

\section{KESIMPULAN}

Diagnosis mixed dementia didasarkan pada adanya gejala klinis yang tipikal dari penyakit Alzheimer dan koeksistensi faktor risiko penyakit serebrovaskuler. Diagnosis mixed dementia ditegakkan berdasarkan temuan klinis dan pemeriksaan pencitraan otak. Tatalaksana mixed dementia berupa pemberian obat golongan inhibitor kolinesterase (donepezil, galantamin, rivastigmin), antagonis NMDA (memantin), antipsikotik, dan antidepresan sesuai indikasi. Tatalaksana faktor risiko hipertensi, diet sehat, dan olah raga harus diberikan untuk mencegah dan memperlambat progresifitas penyakit. Dibutuhkan penelitian lebih lanjut, serta adanya konsensus nasional maupun internasional mengenai diagnosis dan tatalaksana mixed dementia untuk pemahaman lebih lanjut mengenai demensia.

\section{UCAPAN TERIMAKASIH}

Penulis mengucapkan terimakasih kepada Departemen Neurologi Fakultas Kedokteran dan Kesehatan (FKK) Universitas Muhammadiyah Jakarta (UMJ) yang telah membantu penyusunan artikel ini.

\section{KONFLIK KEPENTINGAN}

Tidak ada konflik kepentingan antar penulis dan FKK UMJ.

\section{REFERENSI}

1. Arvanitakis Z, Shah RC, Bennett DA. Diagnosis and Management of Dementia: Review. JAMA. 2019 Oct;322(16):1589-99.

2. Shaji KS, Sivakumar PT, Rao GP, Paul N. Clinical practice guidelines for management of dementia. Indian J Psychiatry. 2018;60(7):S312-28.

3. Schneider JA, Arvanitakis Z, Leurgans SE, Bennett DA. The neuropathology of probable Alzheimer disease and mild cognitive impairment. Ann Neurol [Internet]. 2009 Aug;66(2):200-8. Available from: https://pubmed.ncbi.nlm.nih.gov/19 743450

4. Custodio N, Montesinos R, Lira D, Herrera-Pérez E, Bardales Y, Valeriano-Lorenzo L. Mixed dementia: A review of the evidence. 
Dement

Neuropsychol.

2017;11(4):364-70.

5. Suemoto CK, Ferretti-Rebustini REL, Rodriguez RD, Leite REP, Soterio L, Brucki SMD, et al. Neuropathological diagnoses and clinical correlates in older adults in Brazil: A cross-sectional study. Brayne C, editor. PLOS Med [Internet]. 2017 Mar 28;14(3):e1002267. Available from: https://dx.plos.org/10.1371/journal. pmed.1002267

6. Turner RS, Stubbs T, Davies DA, Albensi BC. Potential New Approaches for Diagnosis of Alzheimer's Disease and Related Dementias. Front Neurol. 2020;11(496):1-10.

7. Jellinger KA, Attems J. Neuropathological evaluation of mixed dementia. J Neurol Sci. 2007 Jun;257(1-2):80-7.

8. Ngandu T, Lehtisalo J, Solomon A, Levälahti E, Ahtiluoto S, Antikainen $\mathrm{R}$, et al. A 2 year multidomain intervention of diet, exercise, cognitive training, and vascular risk monitoring versus control to prevent cognitive decline in at-risk elderly people (FINGER): a randomised controlled trial. Lancet (London, England). 2015 Jun;385(9984):2255-63.

9. Safouris A, Tsivgoulis G, Sergentanis TN, Psaltopoulou T. Mediterranean Diet and Risk of Dementia. Curr Alzheimer Res. 2015;12(8):736-44. 